\author{
Ulfah Nurfadhila \\ Universitas Muhammadiyah \\ Yogyakarta \\ ulfahnurfadhila@gmail.com
}

\section{Penggunaan Model Flipped Classroom dalam Meningkatkan Keterampilan Berbicara Bahasa Arab Siswa}

DOI: $10.18196 / \mathrm{mht} .2114$

\begin{abstract}
This study was conducted to determine the effect of using the flipped classroom model in improving students' speaking skills in Arabic as well as to determine the improvement in speaking skills of students in class X MIPA 1 MAN 1 Yogyakarta after using the flipped classroom model. This type of research was pre-experimental research with the research sample was 33 students of class X MIPA 1 . The data collection methods in this study used an oral test of student learning outcomes in the form of pretest and posttest, questionnaire distribution, and descriptive observation. The data analysis technique was assisted by SPSS program. The research results showed that there was an improvement to the students as they were using the flipped classroom model. From the test data, it could be seen that the improvement in the average posttest score was at 19.61, as it was higher than the average pretest score, at 16.24. The results of the T-test obtained the Sig. (2-Tailed) of $-1.656<0.05$. So, it could be concluded that Ho was rejected and Ha was accepted. It meant that there was a difference between the average pretest and posttest results. The results of the analysis of the student questionnaire in the experimental class showed that approximately 63\% of the overall student questionnaire item agreed to use the flipped classroom model to improve Arabic speaking skills.
\end{abstract}

Keywords: flipped classroom, speaking skills, Arabic, learning outcomes

\title{
ABSTRAK
}

Penelitian ini dilakukan untuk mengetahui pengaruh penggunaan model flipped classroom dalam meningkatkan keterampilan berbicara siswa dalam mata pelajaran bahasa Arab serta untuk mengetahui peningkatan keterampilan berbicara terhadap siswa kelas X MIPA 1 MAN 1 Yogyakarta setelah menggunakan model flipped classroom. Jenis penelitian yang digunakan adalah penelitian pra eksperimen dengan Sampel dalam penelitian sebanyak 33 siswa kelas X MIPA 1 . Metode pengumpulan data dalam penelitian ini menggunakan tes lisan hasil belajar siswa yang berupa pretest dan posttest, penyebaran angket, dan observasi deskriptif. Adapun teknik analisis data menggunakan bantuan SPSS. Hasil penelitian ini menunjukkan bahwa terdapat peningkatan pada siswa dalam penggunaan model flipped classroom. Dari data tes dapat diketahui peningkatan nilai rata-rata hasil posttest yaitu 19,61, lebih tinggi dibandingkan hasil rata-rata nilai pretest yaitu 16,24. Hasil dari Uji T-test diperoleh nilai Sig. (2-Tailed) sebesar $-1,656<0,05$. Maka, dapat disimpulkan Ho ditolak dan Ha diterima, yang artinya bahwa terdapat perbedaan antara rata-rata hasil pretest dengan hasil posttest. Hasil analisis dari angket siswa di kelas eksperimen menunjukkan bahwa sebanyak 63\% dari hasil keseluruhan persentase tiap item angket siswa setuju dengan menggunakan model 
flipped classroom untuk dapat meningkatkan keterampilan berbicara bahasa Arab.

Kata Kunci: flipped classroom, keterampilan berbicara, bahasa Arab, hasil belajar

\section{PENDAHULUAN}

Bahasa Arab adalah bahasa yang tetap bertahan menjadi bahasa internasional, sejajar dengan dua bahasa internasional lainnya yaitu bahasa Inggris dan bahasa Mandarin. Dari fakta yang ada, Arabic numeral dapat memudahkan hitungan dan penulisan angka dari angka romawi yang kurang realistis (Mutholib 2009, 11), padahal hampir di seluruh sekolah yang berbasis Islam di Indonesia memiliki pelajaran bahasa Arab. Hal inilah yang menjadikan bahasa Arab memiliki peran penting dalam pendidikan. Adanya pembelajaran bahasa Arab di sekolah bertujuan untuk memberi pemahaman kepada peserta didik bahwa bahasa Arab telah menjadi bahasa agama Islam, bahasa sumber ajaran Islam, dan bahasa kitab suci Al-Quran sehingga dengan demikian sangat erat kaitannya dengan Kaum Muslimin (Arsyad 2003, 1).

Pembelajaran bahasa Arab sangatlah berbeda dengan pembelajaran bahasa asing lainnya, karena bahasa Arab mempunyai empat keterampilan berbahasa yang menjadi poin penting dalam pembelajaran ini, yaitu keterampilan menyimak (istimâ'), keterampilan berbicara (kalâm), keterampilan membaca (qirâ'ah), dan keterampilan menulis (kitâbah). Dari keempat keterampilan yang telah disebutkan, keterampilan berbicara adalah salah satu yang penting dalam pembelajaran bahasa Arab karena kunci dari pembelajaran bahasa Arab adalah dapat berkomunikasi dengan menggunakan bahasa Arab secara baik dan benar. Sebagai bentuk penggunaan bahasa, berbicara merupakan kegiatan berbahasa yang penting dalam kehidupan sehari-hari. Sebagaimana berbicara merupakan kegiatan yang bersifat aktif dan produktif, kemampuan berbicara menuntut penguasaan terhadap beberapa aspek dan kaidah penggunaan bahasa (Djiwandono 1996, 68).

Keterampilan berbicara juga merupakan keterampilan yang aplikatif dalam bahasa dan merupakan tujuan awal seseorang yang sedang belajar suatu bahasa. Hanya saja, yang perlu diperhatikan dalam menguasai keterampilan berbicara ini agar memperoleh hasil yang maksimal adalah kemampuan dari seorang guru dan metode yang digunakannya, karena dua faktor tersebut memiliki dominasi dalam keberhasilan suatu pembelajaran. Namun pada kenyataannya, banyak kita temukan guru yang mahir dalam berbahasa Arab tapi belum mampu menciptakan suasana kelas secara kondusif dan keterampilan siswa dalam berbicara bahasa Arab pun masih kurang. Padahal, dengan penggunaan kurikulum 2013 saat ini, peserta didik dituntut aktif dalam pembelajaran bahasa Arab dan pengajar harus menyesuaikan dengan model kurikulum 2013. 
Berdasarkan hasil observasi di MAN 1 Yogyakarta, diketahui adanya sebagian siswa yang merasakan kesulitan dalam proses pembelajaran bahasa Arab, khususnya dalam keterampilan berbicara yang faktanya dipaparkan langsung oleh guru pengampu pelajaran bahasa Arab. Kesulitan siswa terdapat pada ketidakbiasaan siswa dalam berbicara bahasa Arab karena pembelajaran di sekolah lebih menekankan pembelajaran pada nahwu dan shorof saja dan kurang menekankan pada aspek komunikasi. Buktinya adalah pada saat pengamatan, ketika siswa mencoba berbicara bahasa Arab, masih ada beberapa kesalahan dalam pemilihan kata dhâmir (kata ganti) ataupun dalam kalimat bahasa Arab siswa. Selain itu, siswa juga kurang memiliki waktu dalam pengaplikasian seperti praktik berbicara bahasa Arab di kelas.

Beberapa faktor di atas berdampak pada keterampilan berbicara siswa dan merupakan permasalahan yang ada pada saat ini. Kurangnya praktik berkomunikasi dan lebih menekankan pada aspek teori mengenai tata bahasa saja menjadikan peserta didik hanya bagus dalam ilmu Nahwu dan Sharaf namun tidak dapat menggunakannya dalam komunikasi sehari-hari. Padahal, keterampilan berbicara merupakan standar keberhasilan seseorang dalam berbahasa Arab. Berdasarkan pengamatan yang telah dilaksanakan, peneliti mencoba memberikan model pembelajaran yang baru dalam pembelajaran bahasa Arab di MAN 1 Yogyakarta. Dalam ilmu pendidikan saat ini banyak model pembelajaran yang telah diciptakan para ahli pendidikan untuk meningkatkan keberhasilan proses pembelajaran di kelas, khususnya dalam meningkatkan keterampilan berbicara. Salah satu model yang digunakan adalah flipped classroom.

Model pembelajaran flipped classroom adalah model pembelajaran yang diberikan oleh para pendidik dengan cara meminimalisasi jumlah instruksi langsung dalam praktik mengajar mereka sambil memaksimalkan interaksi satu sama lain (Yulietri dkk 2015, 6).

\section{METODE PENELITIAN}

Penelitian ini merupakan penelitian praeksperimental yang dilakukan secara kolaboratif dengan guru pengampu bahasa Arab. Metode penelitian praeksperimental ini dilakukan pada satu kelompok saja yaitu kelompok eksperimen, tanpa ada kelompok kontrol. Selanjutnya, kelompok yang diteliti tersebut diberi perlakuan sesuai dengan keperluan penelitian. Peneliti menggunakan desain eksperimen one-group pretest-posttest. Tempat yang dijadikan objek penelitian ini adalah Madrasah Aliyah Negeri 1 Yogyakarta. Populasi dalam penelitian ini adalah kelas X MAN 1 Yogyakarta yang terdiri dari 8 kelas dengan jumlah siswa secara keseluruhan yaitu 244 siswa. Selanjutnya, untuk menentukan sampel penelitian, peneliti menggunakan teknik random sampling yang berjumlah 33 siswa kelas $\mathrm{X}$ MIPA 1 MAN 1 Yogyakarta tahun ajaran 2018/2019. 
Metode pengumpulan data yang digunakan dalam penelitian ini adalah metode tes, angket, dan observasi. Untuk menguji validitas dan reliabilitas penelitian ini, peneliti menguji validitas instrumen dengan jenis validitas isi melalui bidang ahli (expert judgement) kepada dosen pembimbing skripsi, kemudian peneliti mengajukan expert judgement kepada dosen pembimbing ahli untuk dievaluasi tingkat kevalidannya. Peneliti menggunakan teknik analisis data terhadap data tes dengan langkah-langkah sebagai berikut: tes terdiri dari uji mencari mean, uji normalitas, uji homogenitas, dan uji hipotesis. Sedangkan teknik analisis angket dengan menggunakan rumus skala likert. Peneliti melakukan uji validitas dan reliabilitas angket dengan teknik product moment pada statistik. Prosedur penelitian pun sangat diperlukan dalam penelitian ini agar proses penelitian berjalan teratur sesuai dengan yang telah direncanakan. Adapun prosedur penelitian memiliki beberapa tahapan, yaitu tahap persiapan, tahap pelaksanaan, tahap pengolahan, dan tahap penyimpulan data.

\section{PEMBAHASAN}

Peneliti mendeskripsikan data penelitian dengan dua tahapan yaitu tahap persiapan dan tahap pelaksanaan. Tahap persiapan yang dilakukan peneliti adalah dengan melakukan observasi terlebih dahulu ke MAN 1 Yogyakarta pada tanggal 4 Oktober 2018 pada jam pelajaran ke-delapan dan ke-sembilan. Observasi ini dilakukan untuk mengetahui keadaan pembelajaran bahasa Arab siswa, kemampuan siswa dalam berbicara bahasa Arab, dan metode pembelajaran yang digunakan guru dalam proses mengajar bahasa Arab.

Pada tahap pelaksanaan, peneliti melakukan pretest kemampuan berbicara bahasa Arab siswa dengan menggunakan model pendekatan komunikatif. Sebelum diberikan perlakuan di dalam penelitian ini yang berupa percakapan dengan tema الهواية (hobi), siswa dibagi ke dalam beberapa kelompok. Tiap kelompok terdiri dari dua orang. Video pembelajaran yang digunakan dalam penelitian ini berpedoman pada kurikulum pembelajaran di sekolah tersebut yang menggunakan kurikulum 2013, dibantu dengan buku pendukung modul Hikmah. Peneliti memilih modul Hikmah sebagai bahan ajar yang akan diaplikasikan mejadi video pembelajaran berbasis daring. Adapun link youtubenya adalah https://youtu.be/e_eNWy-Fbtw.

\section{Data Hasil Pretest dan Posttest}

Hasil dari pretest dihitung dalam bentuk persentase dengan hasil sebagai berikut:

Tabel 1. Hasil Persentase Nilai Pretest 


\begin{tabular}{cccc} 
Nilai & Kategori & Jumlah & Persentase \\
\hline $21-25$ & $\begin{array}{c}\text { Sangat } \\
\text { baik }\end{array}$ & 2 & $6,06 \%$ \\
\hline $16-20$ & Baik & 17 & $51,51 \%$ \\
\hline $11-15$ & Cukup & 13 & $39,40 \%$ \\
\hline $6-10$ & Sedang & 1 & $3,03 \%$ \\
\hline $1-5$ & Kurang & - & - \\
\hline & Jumlah & 33 & $100 \%$
\end{tabular}

Penilaian dari pretest ini mencakup lima aspek yang terdiri dari kesesuaian isi pembicaraan, ketepatan kosakata, pelafalan, kelancaran, dan kesesuaian dengan kaidah Nahwu. Lima aspek tersebut dapat dilihat pada diagram 1.

\section{Diagram Hasil Tes TerhadapAspek \\ Keterampilan Berbicara}

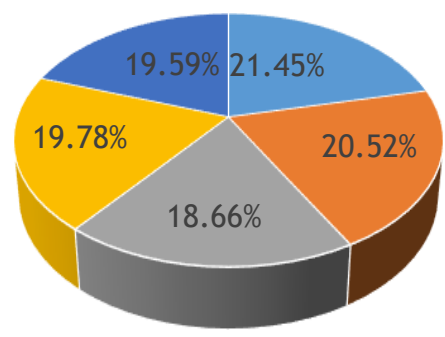

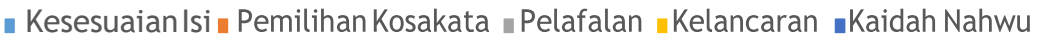

\section{Diagram 1. Pie Chart Persentase Pretest Seluruh Aspek Keterampilan Berbicara}

Diagram 1 menunjukkan bahwa aspek kesesuaian isi pada percakapan siswa sebanyak 21,45\%, aspek pemilihan kosakata siswa sebanyak 20,52\%, aspek pelafalan siswa sebanyak $18,66 \%$, aspek kelancaran siswa sebanyak $19,78 \%$, dan aspek kesesuaian dengan kaidah nahwu sebanyak 17,59\%. Secara keseluruhan, setelah pretest selesai dilaksanakan, diketahui bahwa siswa X MIPA 1 telah menguasai aspek kesesuaian isi dan memiliki nilai yang rendah pada aspek kesesuaian dengan kaidah Nahwu.

Adapun hasil posttest siswa X MIPA 1, dapat dilihat pada tabel 2 serta diagram perbandingan persentase siswa antara pretest dan posttest sebagai 
berikut:

Tabel 2. Hasil Persentase Nilai Posttest

\begin{tabular}{cccc} 
Nilai & Kategori & Jumlah & Persentase \\
\hline $21-25$ & Sangat baik & 16 & $48,49 \%$ \\
\hline $16-20$ & Baik & 11 & $33,33 \%$ \\
\hline $1-15$ & Cukup & 5 & $15,15 \%$ \\
\hline $6-10$ & Sedang & 1 & $3,03 \%$ \\
\hline $1-5$ & Kurang & - & - \\
\hline \multicolumn{2}{c}{ Jumlah } & 33 & $100 \%$
\end{tabular}

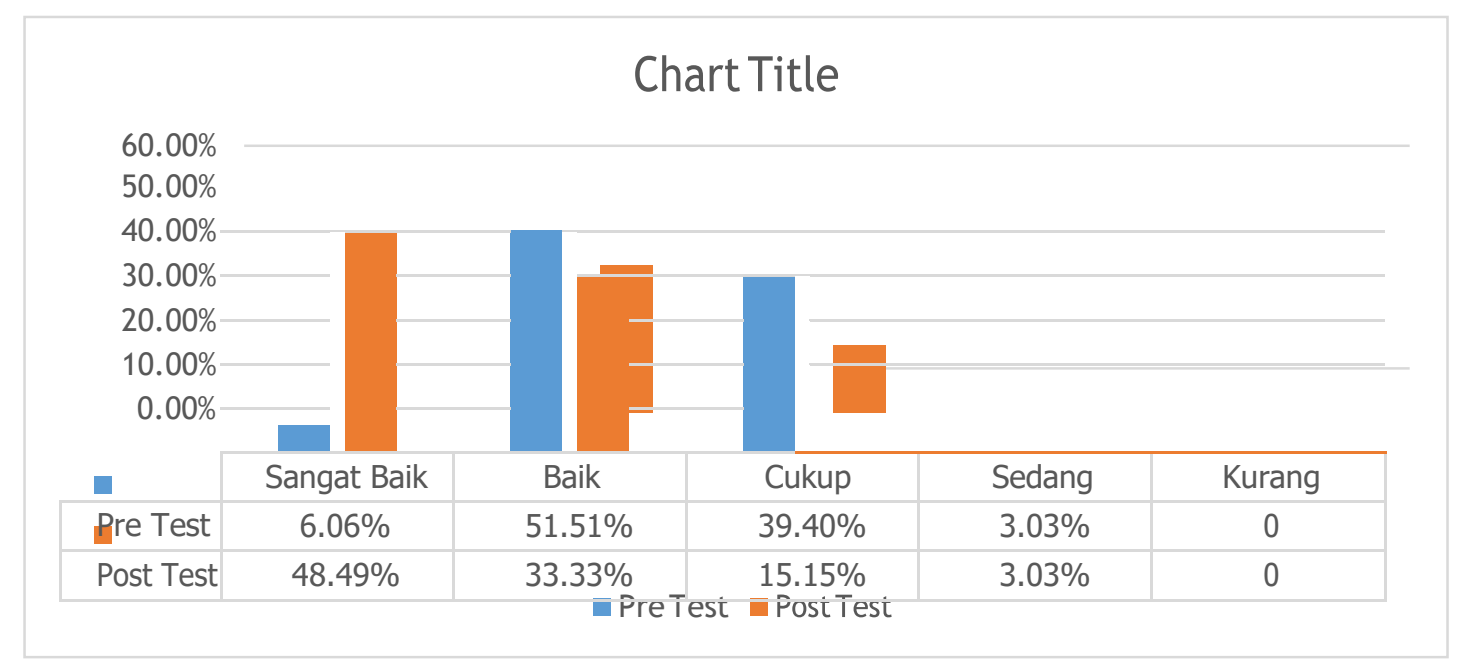

\section{Diagram 2. Histogram Perbedaan Pretest dan Posttest}

Adapun lima aspek dari keterampilan berbicara yang dinilai setelah penggunaan model flipped classroom atau posttest dapat dilihat pada diagram 3: 


\section{Diagram Hasil Tes Terhadap Aspek Keterampilan Berbicara}

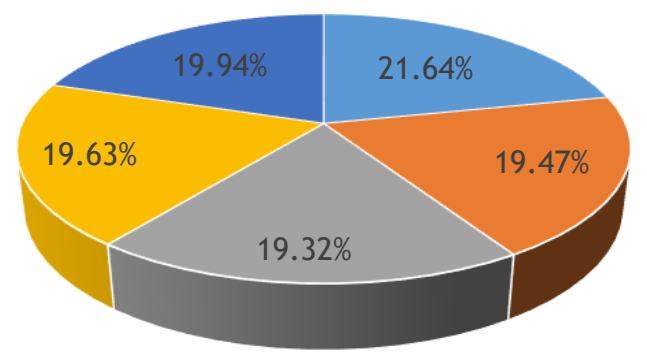

- Kesesuaian Isi Pemilihan Kosakata Pelafalan Kelancaran Kaidah Nahwu

\section{Diagram 3. Pie Chart Persentase Posttest Seluruh Aspek Keterampilan Berbicara}

Diagram 3 menunjukkan bahwa aspek kesesuaian isi pada percakapan siswa sebanyak $21,64 \%$, aspek pemilihan kosakata siswa sebanyak $19,47 \%$, aspek pelafalan siswa sebanyak $19,32 \%$, aspek kelancaran siswa sebanyak $19,63 \%$, dan aspek kesesuaian dengan kaidah Nahwu sebanyak 19,94\%. Secara keseluruhan, setelah posttest selesai dilaksanakan, terjadi peningkatan pada keseluruhan aspek dibandingkan dari hasil pretest sebelumnya.

\section{Data Hasil Observasi}

Sebelum model flipped classroom digunakan, peneliti mengamati keterampilan berbicara siswa dengan bantuan dua observer. Adapun observasi ini berupa penilaian deskriptif yang terdiri dari lima aspek, sebagaimana telah disebutkan sebelumnya. Peneliti mengambil kesimpulan terhadap pengamatan yang telah dilakukan observer sebelum penggunaan model flipped classroom ini yaitu sebagai berikut:

1. Aspek pertama, yaitu dari segi pengucapan makhârijul churûf siswa. Dalam penguasaan terhadap pengucapan makhârijul churûf, hampir seluruh siswa X MIPA 1 dapat menguasai pengucapannya. Hanya beberapa siswa saja yang masih terbata-bata dalam pengucapannya.

2. Aspek kedua, yaitu aktivitas siswa dalam pemilihan kata pada saat berbicara bahasa Arab. Sebagian dari siswa kelas X MIPA 1 telah memiliki kemampuan untuk memilih kata dengan tepat dan sebagian lainnya belum dapat membedakan antara muannats (kata benda perempuan) dan mudzakkar 
(kata benda laki-laki) dalam pemilihan katanya.

3. Aspek ketiga, yaitu kelancaran dalam berbicara bahasa Arab. Siswa X MIPA 1 sebanyak $60 \%$ sudah lancar dalam berbahasa Arab dan sisanya masih terbata-bata.

4. Aspek keempat, yaitu keaktifan siswa dalam mengikuti pembelajaran bahasa Arab. Dari pengamatan yang telah dilakukan, sebagian besar siswa aktif dalam pembelajaran bahasa Arab, sedangkan beberapa sibuk memainkan handphone dan mengobrol dengan temannya sehingga tidak memperhatikan guru dan pasif dalam pembelajarannya.

5. Aspek kelima, yaitu dari segi keberanian siswa berbicara bahasa Arab dan menanyakan hal-hal terkait pelajaran bahasa Arab yang belum dipahami siswa. Peneliti menyimpulkan bahwa siswa X MIPA 1 cukup berani mempraktikkan berbicara bahasa Arab di depan kelas. Hal tersebut terlihat pada saat guru memerintahkan tiap kelompok untuk maju dan mempraktikkan percakapan bahasa Arab di depan kelas, seluruh siswa mau melakukannya.

Demikianlah kesimpulan dari observasi sebelum model flipped classroom diaplikasikan. Peneliti juga merangkum observasi kedua yaitu pengamatan terhadap siswa setelah penggunaan model flipped classroom dengan hasil sebagai berikut:

1. Pada aspek makhârijul churûf, kemampuan siswa sudah cukup baik. Meskipun demikian, siswa harus latihan berbicara bahasa Arab lebih banyak lagi agar dapat mengucapkan makhârijul churûf dengan baik dan benar.

2. Pada aspek pemilihan kata, masih terdapat beberapa siswa yang belum tepat dalam memilih kata pada saat berbicara bahasa Arab dalam konteks percakapan.

3. Pada aspek kelancaran berbicara bahasa Arab siswa, secara keseluruhan terdapat peningkatan dalam berbicara bahasa Arab, akan tetapi ada beberapa yang masih kurang lancar.

4. Pada aspek keaktifan siswa, tidak ada perkembangan dari sebelumnya karena setengah dari siswa yang ada di kelas mau memperhatikan guru dan setengahnya masih sibuk dengan handphone.

5. Pada aspek keberanian siswa, dalam pengamatan ini sudah terlihat lebih baik dari sebelumnya yaitu siswa lebih berani bertanya kepada guru ketika ada materi yang belum dipahami.

Dari pengamatan ini, dapat diambil kesimpulan bahwa pada aspek makhârijul churûf, aspek kelancaran, dan aspek keberanian terdapat peningkatan dibandingkan sebelum penggunaan model flipped classroom. 


\section{Data Hasil Angket}

Data penggunaan model flipped classroom dalam meningkatkan keterampilan berbicara diperoleh dari data angket siswa. Angket tersebut terdiri dari 20 pernyataan untuk kelas eksperimen. Data yang diperoleh akan dicari rentang skornya untuk menentukan kategori tingkat keterampilan berbicara siswa. Kriteria interpretasi skor angket berdasarkan interval untuk menjawab pernyataan keseluruhan siswa untuk kelas eksperimen adalah sebagai berikut:

Tabel 3. Kriteria Interpretasi Skor

\begin{tabular}{ccl} 
No & Skor Siswa & \multicolumn{1}{c}{ Kategori } \\
\hline 1 & $84 \%-100 \%$ & Sangat Setuju \\
\hline 2 & $67 \%-83 \%$ & Setuju \\
\hline 3 & $50 \%-66 \%$ & Netral \\
\hline 4 & $33 \%-49 \%$ & Tidak Setuju \\
\hline 5 & $16 \%-32 \%$ & $\begin{array}{l}\text { Sangat Tidak } \\
\text { Setuju }\end{array}$
\end{tabular}

Selanjutnya, penyelesaian terakhir dengan merangkum hasil pernyataan seluruh responden. Berdasarkan hasil analisis angket terkait peningkatan keterampilan berbicara siswa, sebagian besar siswa setuju bahwa penggunaan model flipped classroom dapat meningkatkan keterampilan berbicara bahasa Arab.

\section{KESIMPULAN}

Berdasarkan hasil perhitungan keterlaksanaan pembelajaran siswa pada pertemuan pertama dan kedua tergolong cukup baik hingga kemudian pada pertemuan ketiga dan keempat berada dalam kriteria sangat baik. Oleh karena itu, dapat dikatakan bahwa pembelajaran dengan menggunakan model flipped classroom telah terlaksana di kelas X MIPA 1 Madrasah Aliyah Negeri 1 Yogyakarta Tahun Ajaran 2018/2019 dengan sangat baik.

Instrumen tes yang digunakan untuk mengambil data penelitian adalah dengan membandingkan hasil pretest dan posttest kelas eksperimen. Pengambilan data keterampilan berbicara terbagi menjadi lima aspek. Dari hasil keseluruhan aspek keterampilan berbicara, nilai rata-rata posttest terlihat lebih tinggi yaitu 19,61 dibandingkan nilai rata-rata pretest yaitu 16,24. Adapun hasil analisis secara statistik terhadap nilai posttest siswa di kelas eksperimen 
menunjukkan bahwa to $>\mathrm{t} \alpha$. Hal ini menunjukkan bahwa terjadi peningkatan keterampilan berbicara bahasa Arab pada siswa setelah dilakukan pembelajaran menggunakan model flipped classroom.

Selanjutnya, berdasarkan hasil analisis terhadap angket siswa di kelas eksperimen dengan rumus skala likert menunjukkan bahwa sebanyak $63 \%$ dari hasil keseluruhan tiap item angket, siswa setuju bahwa penggunaan model flipped classroom dapat meningkatkan keterampilan berbicara bahasa Arab.

\section{REFERENSI}

Arsyad, Azhar. 2003. Media Pembelajaran. Jakarta: Rajawali Press.

Djiwandono, M. Soenardi. 1996. Tes Bahasa dalam Pengajaran. Bandung: Penerbit ITB.

Mutholib, Abdul. 2009. Pengembangan Kurikulum Bahasa Arab (Teori dan Praktik). Kudus: STAIN.

Yulietri, Fradilla, dkk. 2015. "Model Flipped Classroom dan Discovery Learning Pengaruhnya Terhadap Prestasi Belajar Matematika Ditinjau Dari Kemandirian Belajar". Jurnal Teknodika 13, No. 2 (September). 